UDC 371.014.242

DOI: $10.52534 / \mathrm{msu}-$ pp.7(2).2021.70-78

Nataliia M. Vinarchuk, Olha S. Haliuka ${ }^{\star}$, Mariia-Tereza I. Sholovii

Ivan Franko National University of Lviv

79000, 1 Universytetska Str., Lviv, Ukraine

\title{
Features of Using Health-Saving and IC-Technologies in the Formation of a Socially Mobile Teacher in a Pandemic Condition
}

\author{
Article's History: \\ Received: 28.01.2021 \\ Revised: 15.03 .2021 \\ Accepted: 12.04.2021
}

\section{Suggested Citation:}

Vinarchuk, N.M., Haliuka, O.S., \& Sholovii, M.-T.I. (2021). Features of using health-saving and IC-technologies in the formation of a socially mobile teacher in a pandemic condition. Scientific Bulletin of Mukachevo State University. Series "Pedagogy and Psychology", 7(2), 70-78.
Abstract. The new reality caused by the coronavirus pandemic opens up the possibility of updating the content of professional training of socially mobile educators by means of health-saving and information-communication technologies. The purpose of the study is to analyse the features of the use of health and IC-technologies in the process of forming a socially mobile teacher in a pandemic. The research methodology includes theoretical analysis and generalisation of psychological and pedagogical sources, elaboration of legal documents in the field of education, study and generalisation of experience of scientific and pedagogical workers, disclosure of basic theoretical provisions, identification and substantiation of key concepts. The authors present a detailed analysis of the concepts of "health", "health-saving technologies", "information and communication technologies", "social mobility". The purpose and tasks of health-saving and IC-technologies are clarified. Ways to implement and use health-saving technologies in educational institutions during the pandemic COVID-19 have been identified. Methods of application of information and communication technologies in the conditions of distance learning are offered. A number of advantages and disadvantages of ICT in education are identified. The guidelines of successful realisation of a socially mobile teacher in the modern educational reality are determined. It has been found that social mobility as an integrative ability of an individual to adapt to the changing environment and changes dictated by society is perhaps the most important and relevant feature in our time. It is determined that the readiness to implement, combine and use in professional pedagogical activities of health-saving and IC-technologies indicates the formation of social mobility of the teacher. The experience of using health-saving and information-communication technologies by scientific and pedagogical workers of Ivan Franko National University of Lviv in the process of becoming and formation of socially mobile educators in the conditions of the COVID-19 pandemic is described. The practical value of scientific work lies in the substantiation and generalisation of pedagogical conditions for updating the content of professional training of future teachers through the prism of their ability to social mobility

Keywords: COVID-19 pandemic, distance education, ICT, health, healthpreserving educational environment, educational technology, teacher, social mobility, student 


\section{INTRODUCTION}

The COVID-19 pandemic, which affected all spheres of human activity, caused the transformation of the educational process at every level. The situation with coronavirus disease has forced academic workers around the world, including in Ukraine, to reconsider the principles of curriculum and training programmes for future professionals, taking into account the conditions of distance learning.

The new educational reality faced by teachers became the basis for creating quasi-extreme conditions for the work of employees of all structural units. Both teachers and students were forced to study remotely, adapting to different educational platforms. Teachers were faced with the task of finding and analysing the most optimal and easy-to-use tools, online programs, and services to ensure and not break communication with students. After overcoming the severe spread of coronavirus infection, the WHO (World Health Organization) has drawn attention to the importance of organising face-to-face or mixed education, which combines online lessons, conventional learning, and independent work. In this regard, the leaders of the educational process had to organise training in such a way as to prevent or minimise the spread of infection in educational institutions, adhering to the established sanitary and anti-epidemic measures (social distancing, mandatory wearing of protective masks, temperature screening, surface disinfection, etc.).

Given the above-mentioned conditions and the priority of the skills approach, which is one of the modern educational vectors of education development in Ukraine, the authors of this study believe that in the process of becoming a teacher of the new generation nowadays, health-saving and information and communication technologies are extremely important. Today, mastering these technologies and relevant competencies, in the authors opinion, is basic and mandatory during the development of social mobility of the future education specialist, and especially in quarantine.

Problems of the introduction and use of healthsaving technologies in the field of education have been studied by Ukrainian and foreign scientists. In particular, the practical aspects of strengthening and maintaining the health of the individual are widely covered in the studies of V. Yefimova [1], Y. Boychuk [2], T. Lavrenova [3], and V. Shakhnenko [4]. Of particular relevance are studies that reveal various aspects of the development of a culture of health and a healthy lifestyle $[5 ; 6]$, specific issues of creating a healthy environment for the professional activities of teachers and students $[7 ; 8]$.

Ukrainian researchers analysed aspects of the practical application of modern information and communication technologies in professional activities, in particular, they gave a general description of the implementation of IC technologies in the educational process of higher education [9], clarified the role of computer technologies during epidemics [10], identified ways to use distance technologies as a factor of positive impact on improving the quality of education [11].

At the present stage, the problem of development of mobility in the professional training of teachers is reflected in the scientific achievements of scientists who studied the peculiarities of the development of social, professional, socio-professional mobility of specialists in various branches of education: preschool [12], primary [13], general secondary [14].

The analysis of a number of works showed that there is a connection between health-saving and information and communication technologies (S. Dishleva [15], S. Yermakov [16], L. Ivashchenko [17], S. Kanishevsky [18]). At the same time, there is an objective dependence of the information and communication competence of the teacher on his professional and social mobility (L. Familyarska [19], A. Kolomiets [20]). However, aspects of the combination of health-saving and information and communication technologies in the process of professional training of teachers who are able to quickly adapt to changing conditions and act in unusual situations, in particular during a pandemic, have not yet been studied. The authors of this study believe that the willingness to implement, combine, and use healthsaving and IC technologies in professional pedagogical activities indicates the completeness of social mobility of the teacher.

The purpose of the study is to analyse the characteristic features of the use of health-saving and information and communication technologies in the development of a socially mobile teacher in a pandemic.

The objectives of the study:

- to analyse the basic concepts of research "health", "health-saving technologies", "information and communication technologies", "social mobility";

- to find out the purpose and tasks of health-saving and IC technologies;

- to identify ways to implement and use the abovementioned technologies in educational institutions during the pandemic COVID-19;

- to offer ways of application of IC technologies in the conditions of distance learning;

- to trace the connection between the use of healthsaving and information and communication technologies in the development of a socially mobile teacher during the pandemic.

\section{METHODOLOGY}

The object of research is the personality of a socially mobile teacher, and the subject is health-saving and IC technologies as factors in the formation of a socially mobile teacher in a pandemic. The methodological basis of the work is the scientific provisions of the humanistic paradigm of the philosophy of education, the theory of the content of education, the theory of systems; methodological approaches (skills, integrative, noospheric, narrative, synergetic, acmeological, civilisational, historical-pedagogical, fundamental, paradigmatic, ambivalent, structural-activity, systemic); theories of development and self-development of personality; modern didactic provisions on the content, methods, and technologies of higher education.

The research methodology includes theoretical 
analysis and generalisation of classical and modern philosophical, psychological pedagogical, sociological and methodological sources, elaboration of normative legal documents in the field of education (Law of Ukraine "On Education” of 05.09.2017 № 2145-VIII [21]; Statute (Constitution) WHO: international document of 22.07.1946 [22], Law of Ukraine "On Childhood Protection" of April 26, 2001 № 2402-III [23], Law of Ukraine "On Amendments to Section II "Final Provisions" of the Law of Ukraine "On Amendments to Certain Laws of Ukraine on Provision of Treatment of Coronavirus Disease (COVID-19)" on prolongation of validity in connection with the threat of increasing incidence of coronavirus disease (COVID-19)" of 19.06.2020 № 737-IX [24]; Some issues of the organisation of distance learning: Order of the Ministry of Education and Science of 08.09.2020, Resolution of the Chief State Sanitary Doctor № 50 of 22.08.2020 “On approval of the Provisional Recommendations on the organisation of anti-epidemic activities in educational institutions during the quarantine period in connection with the spread of coronavirus disease (COVID-19)" [25], study, generalisation, and testing of experience of research and teaching workers, disclosure of basic theoretical principles, identification and justification of key research concepts.

At the first stage of the study, the authors singled out and comprehended the scientific problem of forming a socially mobile teacher by means of health-saving and information and communication technologies, substantiated the relevance, timeliness, and novelty of the phenomenon being studied in the COVID-19 pandemic. The authors have formulated the title, defined the purpose and objectives, identified the object and subject of research, as well as the choice of research methods (analysis, synthesis, abstraction, axiomatic method, induction, modelling, method of analogy, observation, generalisation, and systematisation of conceptual theoretical foundations).

The second stage involves recording the initial data about the object under study, study itself and description of previous scientific experience, identification of causal relationships, selection of factual material with a detailed analysis of research concepts and approaches to interpreting scientific and educational definitions of "health-saving technologies", "information and communication technologies", "social mobility". The authors of this study have developed legal documents that regulate and prove the importance of implementing the above-mentioned technologies in the educational process in the context of the skills approach and pedagogical conditions of distance and mixed learning. Research focuses on creating a comfortable and safe health education environment for applicants and educators, so the authors provide practical advice and guidance on the use of health technologies by educators, especially in the current context of the COVID-19 pandemic. The second stage of the work also reveals the advantages and disadvantages of information and communication technologies and proposes ways of using IC technologies in educational institutions during distance learning on the example of the experience of Ivan Franko National University of Lviv.

At the third stage of the study, an integrative link between health-saving and information and communication technologies was established using a synthetic method, which, according to the authors, are factors in the development of a socially mobile education specialist in the new quarantine reality. The formulated results and prospects of further research on this topic are presented in the conclusions of the study.

\section{RESULTS AND DISCUSSION Health-saving technologies}

Nowadays, the issue of training students in quarantine conditions that are not threatening for staying in an educational institution is especially acute. Who should facilitate this and organise safe learning? First of all, the administration of the educational institution, which is responsible for ensuring the availability of personal protective equipment for workers (protective masks and eye protection), systematic disinfection and ventilation of premises, control and verification of compliance with anti-epidemic norms. However, a critical commitment to students, parents, education facility, and society, in particular, lies with the educator, who must be prepared morally, physically, and professionally for such an unpredictably heavy "burden". That is why it is now very important for educators to use health-saving technologies in their work, which will be able to increase the effectiveness of the educational process, to form values for teachers and parents aimed at preserving and strengthening the health of children.

Let us explain the concept of "health" from the point of view of medicine and pedagogy. In the international community, the definition of health is set out in the Preamble to the WHO Statute: "Health is a state of complete physical, spiritual and social well-being, not only the absence of disease or physical disabilities" [22]. World science has developed a holistic view of health as a phenomenon that integrates at least four of its areas or components - physical, psychological (mental), social (public) and spiritual. All these components are inseparable from each other. O. Shchipanovska defines the term "health" as "a set of physical, spiritual, social qualities of a person, which is the basis for longevity and a necessary condition for the implementation of creative plans, high efficiency, family, birth and upbringing of children" [26, p. 45].

Researchers characterise the main components of a healthy lifestyle, which include: rational nutrition, physical activity and conditioning, personal hygiene, absence of bad habits, positive emotions, intellectual development, work and rest, self-control over health [27, p. 36]. According to N. Patkova, "from the standpoint of a modern teacher, a healthy person is one who effectively copes with stress and is able to prevent and resolve conflicts; makes responsible decisions; finds his or her sociocultural niche; is mobile in a changing labour market; not only adapts to external conditions but meaningfully rebuilds them, thereby improving public health" [28, p. 10].

The authors of this study believe that in the context of the pedagogical point of view, it is appropriate to talk about the health of students as of main subjects of the professional activity of the teacher. Let us turn to the definition given by 
O. Kaplun, that children's health is "a social value, an integral part of social wealth, and therefore the development of a healthy lifestyle, health culture is considered as a matter of national importance, the global task of society, school, family, the child himself" [29, p. 298]. Accordingly, an important component in the implementation of the main objectives of education are health-saving technologies, which indicate the prioritised and unprecedented importance of students' health.

L. Kravchuk interprets health-saving technologies as those that create "safe conditions for staying, studying and working in an educational institution and solve the problem of rational organisation of the educational process (taking into account age, gender, individual characteristics and hygienic standards), compliance with educational and physical loads to the child's capabilities" [30, p. 44]. According to the researcher, the purpose of health-saving educational technologies is to "...provide the conditions of physical, social, spiritual, mental health that contributes to the comfort of the individual..." [30, p. 45]. M. Smirnov gives the following definition of health-saving technologies - it is "a functional system of organisational tools for managing educational, cognitive and practical activities of students, which scientifically and instrumentally ensures the preservation and promotion of health" [31]. L. Rybalko claims that the concept of "health-saving technologies" combines all areas of the institution's activities to form, maintain and improve the health of students. The researcher systematises and identifies the main approaches to the interpretation of the definition of "health-saving technologies":

- systematic - an indicator of the quality of educational technologies;

- activity - the optimal combination of conventional learning technologies with the principles, methods, and techniques aimed at supporting and maintaining health;

- skills - technologies for the development of healthsaving and health-developing competencies, learning the basics of health, a healthy lifestyle, forming a picture of the world of a healthy personality;

- integrated - educational and methodical complex of recreational and physical activities and healthcare measures;

- environmental - creating a healthy educational environment;

- personality-oriented - providing training and education taking into account the individual, age and psychophysiological characteristics of students [32].

The practical implementation of health-saving technologies in the educational process is clearly represented in the classification of N. Tolokonnikova [33], who describes the types of health-saving technologies in the modern school in her study, where different approaches to healthcare, methods, and forms of work are being applied. The authors of this study believe that the technologies presented by the researcher can be interpreted as universal for all students of each branch by analogy. The authors provide the relevant adaptation of this classification:

1. Medical and hygiene technologies, which include a range of measures aimed at maintaining proper hygienic conditions in accordance with the regulated sanitary norms and the functioning of medical offices in educational institutions.

2. Recreational and physical technologies aimed at the physical development of students. Mostly these technologies are implemented in physical education classes and sports sections' activities.

3. Ecological health-saving technologies that help to educate students to love and care for nature, which strengthens their spiritual health.

4. Life safety technologies implemented by labour protection specialists.

5. Educational health-saving technologies, which are carried out using pedagogical techniques, approaches to solving emerging problems [33, p. 91] (Fig. 1).

\section{TYPES OF HEALTH-SAVING TECHNOLOGIES}

\begin{tabular}{|c|c|c|c|c|}
\hline $\begin{array}{l}\text { Medical and } \\
\text { hygiene } \\
\text { technologies }\end{array}$ & $\begin{array}{l}\text { Recreational } \\
\text { and physical } \\
\text { technologies }\end{array}$ & $\begin{array}{c}\text { Ecological } \\
\text { health-saving } \\
\text { technologies }\end{array}$ & $\begin{array}{c}\text { Life safety } \\
\text { technologies }\end{array}$ & $\begin{array}{l}\text { Educational } \\
\text { health-saving } \\
\text { technologies }\end{array}$ \\
\hline
\end{tabular}

Figure 1. Types of health-saving technologies

Thus, health-saving technologies in education are technologies designed to fulfil the tasks of modern education - to preserve, improve and enhance the health of students, teachers, and parents. The main goal of healthsaving technologies is the education of a culture of values in the context of the child's conscious attitude to his own health and the health of people around him.

The authors of this study believe that the teacher directly chooses health-saving technologies in accordance with the activities and priorities of the educational institution, the state of students' health, available human resources, logistics, established level of trust and cooperation with parents, environmental factors, ability to effectively monitor the efficiency of the implemented technologies. In the context of the development of social mobility, the issue of psychological readiness of teachers to restructure their professional activities in a pandemic becomes relevant. The introduction of health-saving technologies, self-improvement, self-education, the level of awareness of responsibility for their own health and the health of their students - are the guidelines for the successful implementation of a socially mobile teacher in modern educational reality. 
Information and communication technologies Informatisation of all spheres of human life does not pass over education. Consistent entry of information and communication technologies into the educational process changes the conventional views on education in Ukraine. The use of IC technologies enables the existence of quality distance education, which, in turn, is an effective way to increase the intellectual potential of the population, has a number of advantages for both teachers and students. Distance education is especially relevant during a pandemic when the usual forms of learning become impossible due to quarantine conditions. Information and communication technologies make it possible to blur the boundaries between cities and villages, unite students and, at the same time, prevent the spread of disease. All these factors are a prerequisite for improving the quality of education, provide additional emotional and intellectual incentives for education, promote the principles of continuity and regularity, even during quarantine restrictions. First of all, let us pay attention to the definition of "information environment", which, according to the authors, is a condition, a field of functioning and implementation by the teacher of the principles, methods, and means of information and communication technologies.

According to E. Levina, the information environment includes many information objects and connections between them, as well as tools and technologies for searching, storing, broadcasting, processing, creating, and distributing knowledge, tools for reproducing audio-visual information; organisational and legal structures that support information processes [34, p. 5019-5031]. According to G. Shvachych, the "information and communication technologies" (ICT) is not unambiguous. The author defines IC technologies as a set of various technological tools and resources used to provide the process of communication and the creation, distribution, storage, and management of information. These technologies are computers, the Internet, radio and television, as well as telephone communication [35, p. 11]. Order No. 1115 of Ministry of Education and Science of 08.09.2020 defines the concept of information and communication (digital) technologies of distance learning, which is interpreted as "technologies for creating, accumulating, storing, and accessing electronic educational resources in educational subjects (integrated courses), as well as providing organisation and support of the educational process using specialised software and means of information and communication, including the Internet" [36].

The introduction of IC technologies in the educational process requires qualitative alternative educational and methodological support. This necessitates the use of computer and software means of transmitting and storing information: electronic libraries, archives, textbooks and multimedia, local and global educational networks and platforms, reference and information retrieval systems. Given the need for quality training of students in accordance with educational plans and programmes, especially in the conditions of coronavirus infection, teachers need to pay attention to modern electronic educational resources and online tools for distance education, which are also means of IC technologies. The authors of this study offer ways to use information and communication technologies in the educational process in terms of distance learning, presented in Figure 2.

Notably, the use of information and communication technologies in the educational process has a number of advantages (Fig. 3).

\begin{tabular}{|c|c|}
\hline Use of electronic lecturers, simulators, textbooks, encyclopedias \\
\hline $\begin{array}{c}\text { Development of situational role-playing and intellectual games using artificial intelligence } \\
\text { Modeling of processes and phenomena }\end{array}$ \\
\hline $\begin{array}{c}\text { Conducting interactive educational teleconferences } \\
\text { Creation, active and systematic work and support of sites of educational institutions } \\
\text { contions control systems and testing of knowledge and skills of students (use of } \\
\text { Preparation of presentations of educational material }\end{array}$ \\
\hline
\end{tabular}

Figure 2. Methods of information and communication technologies' application in the educational process in the conditions of distance learning

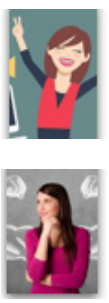

Increasing the motivation of students to study

Development of the student's personality
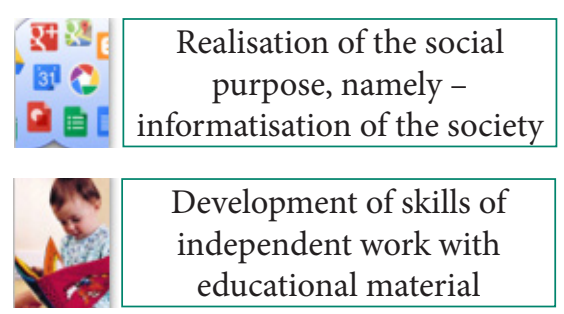

Development of skills of independent work with educational material
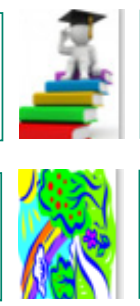

Intensification, systematisation, and continuity of the educational process

Improving the effectiveness of training through individualisation

Figure 3. The advantages of using IC technologies in the educational process 
The authors can state that the use of computers in education has led to the emergence of a new generation of information technologies in education, which in today's instability has become, without a doubt, the "life jacket" of educators. The COVID-19 pandemic has reaffirmed the indisputable principles of distance education. After all, in order to productively use IC technologies, it is necessary to provide educational institutions with computers, access to global and local educational networks, periodically train teachers to improve teaching skills, which, in fact, contributes to the development of social mobility - the ability to have flexible and comfortable work of teachers in new educational realities.

\section{Development of a socially mobile teacher}

Social mobility as an integrative ability of an individual to adapt to the changing environment and changes dictated by society is perhaps the most important and relevant feature of modernity. Socially mobile education specialist is becoming competitive and demanded in the labour market, because speed and efficiency, flexibility and adaptability, innovation and mobility are the main characteristics of the teacher of the new conditions of modern educational space.

When it comes to the development of social mobility, first of all, adaptation to the environment, new operating conditions are meant, in particular, the authors focus on the study of coronavirus reality, which represents new circumstances for the professional activities of teachers. Educators, teachers, lecturers, in accordance with laws and regulations, are required to work in educational institutions in compliance with anti-epidemic norms and rules - in full-time or mixed learning [25], as well as be prepared for distance learning if the morbidity level in the region exceeds acceptable levels or the country introduces a general strict quarantine [36]. This makes it possible to assert the existence of full-time quarantine (offline) and distance (online) educational environments in which teachers with an established ability to social mobility should work. In this aspect, it is extremely important to organise the educational process in such a way that unforeseen circumstances, such as forced transitions from full-time/mixed to distance learning, were "painless", comfortable and flexible for both students and teachers.

The authors agree with O. Kivliuk, who notes that conducting classes using IC technologies requires teacher's skills for effective implementation of information and communication and health-saving technologies, knowledge of methods of using these technologies in education, taking into account the age characteristics of students [37] Additionally, in a pandemic, teachers need to pay special attention to the well-being and health of students.

The experience of the academic workers of Ivan Franko National University of Lviv shows a real picture of the process of establishment and development of social mobility of education professionals during quarantine. At the beginning of the pandemic, when national restrictions were introduced, the Rector's Order approved a temporary transition to distance learning at the university. To support communication with students, teachers used various online platforms and video conferencing services, social networks and messengers, including Zoom, Google-Meet, Skype, Viber, Telegram, etc. However, due to the prompt work of the University Information Support Department, it was possible to systematise and establish feedback with students: teachers switched to the corporate platform Microsoft Teams, and students quickly gained access to university-wide corporate mail at lnu.edu.ua. Educators have begun to use cloud services, including Office 365, to provide access to lecture and seminar materials, as well as to collect and organise practical tasks completed by students.

The most fortunate were those teachers who actively worked in the online environment of e-learning before the quarantine, developed in the MOODLE system, which is one of the means of implementing distance learning at the university. This platform allows the teacher to independently create and manage distance courses, control access to educational resources, use time constraints, create their own knowledge assessment systems, control the timing of completed and submitted testing tasks, allow or prohibit students to retake control tasks (midterm or final tests, exams), etc.

MOODLE provides convenient content management tools and various forms of organisation of classes. The distance course can contain various elements: lectures, practical tasks, independent work, forum. One can use text, presentations, tables, charts, graphs, videos, weblinks, auxiliary files, etc. at the same time. Based on the results of the completed tasks, the teacher can give points and comment on the work. The information-analytical report on the results of the survey on the state of use of distance learning technologies in higher education institutions of Ukraine identifies the level of skills and abilities to use distance learning technologies among academic workers, which is quite mediocre, as less than half (44.5\%) respondents used such tools regularly [38].

In addition to the MOODLE system, academic workers began to keep records of students' achievement in electronic journals of academic groups in the automated system "Dean's Office", which performs the main functions of computerisation of administrative and educational processes. Thus, the situation with distance learning has contributed to the fact that the faculties of the university have accelerated the transition to electronic documentation and recording the results of academic performance of students. Now all modules of AS "Dean's Office" are actively functioning: questionnaires of students and employees in which all orders concerning the specific person (about enrolment/dismissal, transfer to vacant places of the state order, change of conditions (forms) of training/employment, change of a surname etc.) are reflected and fixed; curricula; journals of current control and formation of examination information; accounting for the pedagogical workload of academic workers; preparation of the educational schedule.

Despite the available resources and technical capabilities, not all academic workers were able to successfully adapt to the realities of work, as they faced a number of problems caused by objective or subjective reasons 
for partial loss of communication with the coverage of students in the study group (poor mobile and Internet communication quality, lack of computer aids, problems of objective evaluation of students' work, difficulties with identification of students during credit and examination control, etc.). The problem of students passing various types of practice, in particular pedagogical, became especially acute. It was difficult for those workers who either rarely or did not use information and communication technologies in teaching before the quarantine. At the same time, the staff of the e-learning centre, marketing and communication department, ЄДЕБО (The state electronic database on education) department systematically conducted online seminars, webinars, trainings, methodical meetings on the practice of implementation and use of web resources, distance learning, online communication, including work in MS “Teams", educational platform MOODLE, "Dean's Office" system.

As soon as the situation with COVID-19 stabilised, educational institutions, including Ivan Franko National University of Lviv, switched to a mixed form of education: lectures were held remotely using digital technologies, and practical - in a face-to-face format in groups with a limited number of people, ensuring the maximum distance between students. Immediately before the start of classes, the teacher surveyed participants in the educational process about their health and the presence of symptoms of respiratory disease. If signs of acute respiratory infection were detected, students wore a mask, were temporarily isolated in a special room, and the dean's office of the faculty made an agreed decision to address the student to a health facility.

The use of health-saving technologies by academic workers of Ivan Franko National University of Lviv during the pandemic is manifested in the development of students' ability to apply skills of caring for their own health in temporarily suspended learning. Indoor gyms and stadiums, swimming pools and dance studios, a ban on leaving the apartment unnecessarily, etc. - these and other forced restrictions of the quarantine should not harm the lives and health of both students and teachers.

The educational environment of Lviv University meets sanitary and anti-epidemic norms and safety requirements for the life and health of students and employees. The higher education institution has developed a number of orders and instructions aimed at guaranteeing fire safety and civil protection standards. In order to preserve the mental health of all participants in the educational process, especially during the coronavirus SARS-CoV-2, as well as the humanisation of relations in student and teaching staff, there is the Psychological Service of the University, which provides free services. Health-improving activities and educational work to promote a healthy lifestyle are carried out by the Sports Club of the Department of Physical Culture and Sports, which provides the organisation of mass physical culture and health and sports activities for employees and students. Near the buildings of the university faculties, in particular the faculty of pedagogical education, the territory was landscaped, a recreational zone was arranged, where, in accordance with the recommendations of the Chief Sanitary Doctor, practical classes of Master's educational programs of the faculty took place.

The results of observations generally indicate the completeness of social mobility in academic staff. However, it should be noted that education specialists, depending on cognitive-psychological and psychological, individualpersonal characteristics, level of awareness of health-saving and IC technologies, flexibility and adaptability, in different time parameters (short-term/long-term) were able to adapt to unforeseen quasi-extreme conditions of the COVID-19 pandemic. One way or another, the teachers of Ivan Franko National University of Lviv overcame quarantine barriers and successfully adapted to new working conditions. As a result, subsequent changes or transitions from full-time to distance learning are not a problem today, because teachers already know the algorithm of work, and students can easily adapt to any circumstances. The authors of this study can say that now, on the contrary, it has become much more comfortable to communicate and receive feedback from students, organise scientific and practical meetings or consultations, reporting conferences or meetings.

According to the authors' opinion, the integration of a comprehensive approach to solving educational problems using the above-mentioned technologies is the factor shaping the social mobility of modern specialists in the field of education. The combination of health-saving and information and communication technologies in the modern realities of the pandemic is a necessary link, a kind of an "elevator" that unites and/or allows a smooth transition from one (full-time quarantine) to another (distance) educational environment. The COVID-19 pandemic in the educational trajectory is a challenge that has turned problems into opportunities and taught educators around the world to work in a new direction, improve classical learning technologies, implement innovative approaches and systems, create flexible educational trends.

\section{CONCLUSIONS}

Thus, the authors have found that the use of health-saving and information and communication technologies contributes to the development of a socially mobile educator during the COVID-19 pandemic. This phenomenon is manifested in the ability of education professionals for comfortable quick adaptation, restructuring of the algorithm in a changing environment.

The technologies studied by the authors are separate systems of the educational and methodical complex of work with students. They are aimed at providing optimal ways of professional and educational activities of subjects. The pedagogical conditions for the use of health-saving technologies in the quarantine educational process are face-to-face/mixed (offline), and information and communication - distance (online) learning, which allows teachers to systematically and continuously carry out the educational process without endangering the life and health of students. Thus, the teacher becomes socially mobile, because, owing to the above-mentioned technologies, one successfully adapts to the unpredictable conditions of modern educational realities. 
The authors of this study believe that the theoretically analysed aspects of the studied educational technologies will draw the attention of scientists to a more detailed study of certain methodological and practical components. It should be noted that this may be an impetus for updating the content of professional training of future teachers through the prism of their ability to social mobility. The authors see prospects for further research in the implementation and practical realisation of the proposed health and IC technologies in the process of training future professionals in educational specialisations.

\section{REFERENCES}

[1] Yefimova, V.M. (2010). Health protecting technologies in the context of pedagogical investigations. Pedagogics, Psychology, Medical-Biological Problems of Physical Education and Sports, 1, 57-60.

[2] Boychuk, Yu.D. (Ed.). (2017). General theory of health and healthcare. Kharkiv: Publisher Rozhko S.G.

[3] Lavrenova, T.P. (2013). Application of innovative health technologies in primary school. Svit Vykhovannia, 1, 10-12.

[4] Shakhnenko, V.I. (2015). Through the concept of health - to preserve and strengthen the health of students as a condition for the preservation of the nation. Osnovy Zdorovia, 1, 4-9.

[5] Boiko, O. (2014). Formation of a healthy lifestyle. Zavuch, 2, 12-14.

[6] Svyrydenko, S. (2012). Technology of forming the culture of schoolchildren`s health. Pochatkova osvita. Shkilnyi svit, $25,2-3$

[7] Ivanova, L.I. (2007). Preparation of future teachers of physical culture for physical culture and health work with students of secondary school (Doctoral dissertation, National Pedagogical Dragomanov University, Kyiv, Ukraine).

[8] Hurinenko, N.O., \& Rybalka, O.Ya. (2007). Educational health technologies are a way to preserve the health of school children. Retrieved from http://dspace.pnpu.edu.ua/handle/123456789/3276.

[9] Dyshko, O.L., Zubekhina, T.V., \& Pavlyshyna N.B. (2017). Information and communication technologies in the organisation of bachelors' e-learning (using the example of specialities "Tourism" and "Social work"). Information Technologies and Learning Tools, 59(3), 76-86.

[10] Osadcha, K.P., Osadchiy, V.V., \& Kruglyk, V.S. (2020). The role of information and communication technologies in epidemics: An attempt at analysis. Ukrainian Journal of Educational Studies and Information Technology, 8(1), 62-82.

[11] Hevko, I., \& Nevmerzhytska, O. (2019). The role of information and communication technologies in the contemporary concept of distance education. Youth \& Market, 2(169), 41-45.

[12] Boiko, H.O. (2016). Teacher's social mobility: Theoretical and methodological aspects. Pedagogic and Psychology of Professional Education, 2, 66-75.

[13] Prima, R.M. (2008). Professional mobility of the future primary school teacher. Lutsk: RVV "Vezha” Lesya Ukrainka Volyn National University.

[14] Sachuk, Yu. (2015). Diagnostics of the social and professional mobility of future teachers of computer science. Lesya Ukrainka Eastern European National University Scientific Bulletin. Pedagogical Sciences, 1, 104-109.

[15] Dyshleva, S.M. (2007). Information and communication technologies (ICT) and their role in the educational process. Retrieved from http://osvita.ua/school/technol/6804.

[16] Iermakov, S.S. (2008). Scientific information aspects of physical education. In Actual problems of physical education: Materials of the II electronic scientific conference (pp. 3-6). Kharkiv.

[17] Ivashchenko, L.Ia. (2010). Strengthening the health orientation of physical training of servicemen at the stage of reforming the system of physical training of the Armed Forces of Ukraine. Bulletin of the National University of Defense of Ukraine, 6, 11-15.

[18] Kanishevskyi, S.M. (1999). Scientific-methodical and organisational bases of physical self-improvement of students. Kyiv: IZMN

[19] Familiarska, L.L. (2017). Development of information and communication mobility of the teacher in the educational environment of postgraduate education (Doctoral dissertation, Zhytomyr Ivan Franko State University, Zhytomyr, Ukraine).

[20] Kolomiiets, A.M. (2007). Information culture of primary school teachers. Vinnytsia: VSPU.

[21] Law of Ukraine No. 2145-VIII “On Education”. (2017, September). Retrieved from https://zakon.rada.gov.ua/laws/ show/2145-19\#Text.

[22] Statute (Constitution) of the World Health Organization. (1946, July). Retrieved from https://zakon.rada.gov.ua/ laws/show/995_599\#Text.

[23] Law of Ukraine No. 2402-III “On the Protection of Childhood”. (2001, April). Retrieved from https://zakon.rada.gov.ua/ laws/show/2402-14

[24] Law of Ukraine No. 737-IX "On Amendments to Section II "Final Provisions" of the Law of Ukraine "On Amendments to Certain Laws of Ukraine Concerning the Provision of Treatment of Coronavirus Disease (COVID-19)" to Extend the Term of Action Due to the Threat of Morbidity Coronavirus Disease (COVID-19)". (2020, June). Retrieved from https://zakon.rada.gov.ua/laws/show/737-20\#Text.

[25] Resolution of the Chief State Sanitary Doctor of Ukraine No. 50 "On Approval of Anti-Epidemic Measures in Educational Institutions for the Period of Quarantine in Connection with the Spread of Coronavirus Disease (COVID-19)”. (2020, August). Retrieved from https://moz.gov.ua/golovnij-derzhavnij-sanitarnij-likar-ukraini. 
[26] Shchipanovska, O.R. (2012). Individual health as a multidimensional socio-cultural phenomenon. Scientific Journal of National Pedagogical Dragomanov University. Series 12: Psychological Sciences, 37(61), 44-49.

[27] Shepelenko, T.V., Buts, A.M., \& Bodrenkova, I.O. (2018). Physical education in the formation of a healthy lifestyle. Kharkiv: UkrDUZT.

[28] Patkova, N.Y. (2009). About preservation of health of the teacher in professional activity. Bulletin of the Cherkasy Bohdan Khmelnytsky National University. Series "Pedagogical Sciences", 148, 79-82.

[29] Kaplun, O.A., Kutsenko, L.M., \& Provotorova, A.S. (2017). Modern approaches to creating a healthy educational environment in the school. In Health pedagogy: Materials of the VII All-Ukrainian scientific-practical conference (pp. 298-302). Chernihiv.

[30] Kravchuk, L.S. (2015). Health-saving technologies are the leading condition of students' educational activity. Collection of Scientific Works of the Khmelnytsky Institute of Social Technologies of the University "Ukraine”, 10, 44-47.

[31] Smirnov, N.K. (2002). Health-saving educational technologies in modern school. Moskow: APK \& PRO.

[32] Rybalko, L.M. (2018). Essence and content of health-saving technologies in the system of physical education of student youth. Scientific Journal of National Pedagogical Dragomanov University. Series 15: Scientific and Pedagogical Problems of Physical Culture (Physical Culture and Sports), 3K(97), 478-482.

[33] Tolokonnikova, N., \& Vasylkiv, O. (2013). The use of health retaining technology in the modern school. Obrii, 2(37), 90-92.

[34] Levina, E.Y., Masalimova, A.R., Kryukova, N.I., Grebennikov, V.V., Marchuk, N.N., Shirev, D.A., Renglikh, K.A., \& Shagieva, R.V. (2017). Structure and content of e-learning information environment based on geo-information technologies. Eurasia Journal of Mathematics, Science and Technology Education, 13(8), 5019-5031.

[35] Shvachych, H.H., Tolstoi, V.V., Petrechuk, L.M., Ivashchenko, Yu.S., Huliaieva, O.A., \& Sobolenko, O.V. (2017). Modern information and communication technologies. Dnipro: NMetAU.

[36] Order of the Ministry of Education and Science of Ukraine No. 1115 "Some issues of the organisation of distance learning”. (2020, September). Retrieved from http://search.ligazakon.ua/l_doc2.nsf/link1/RE35224.html.

[37] Kyvliuk, O.P. (2006). Analysis of scientific research on the issue of propaedeutics of computer science in primary school. Informatyka ta Informatsiini Tekhnolohii v Navchalnykh Zakladakh, 6, 69-72.

[38] Information-analytical report on the results of the survey on the state of use of distance learning technologies in higher education institutions of Ukraine. (2020). Retrieved from https://cutt.ly/5zdreMb.

\section{Наталія Миколаївна Вінарчук, Ольга Степанівна Галюка, Марія-Тереза Ігорівна Шоловій}

Львівський національний університет імені Івана Франка

79000, вул. Університетська, 1, м. Львів, Україна

\section{Особливості використання здоров'язбережувальних та IК-технологій у формуванні соціально мобільного педагога в умовах пандемії}

Анотація. Нова реальність, спричинена пандемією коронавірусної хвороби, розкриває можливості оновлення змісту професійної підготовки соціально мобільних педагогів засобами здоров’язбережувальних та інформаційнокомунікаційних технологій. Метою дослідження є аналіз особливостей використання здоров'язбережувальних та ІК-технологій у процесі формування соціально мобільного педагога в умовах пандемії. Методологія дослідження включає теоретичний аналіз та узагальнення психолого-педагогічних джерел, опрацювання нормативно-правових документів у сфері освіти, вивчення й узагальнення досвіду роботи науково-педагогічних працівників, розкриття основних теоретичних положень, виокремлення й обгрунтування ключових понять. Авторами подано детальний аналіз понять «здоров’я», «здоров’язбережувальні технології», «інформаційнокомунікаційні технології, «соціальна мобільність». 3’ясовано мету та завдання здоров'язбережувальних та IК-технологій. Визначено шляхи впровадження та використання здоров'язбережувальних технологій у закладах освіти в період пандемії. Запропоновано способи застосування інформаційно-комунікаційних технологій в умовах дистанційного навчання. Визначено низку переваг і недоліків використання ІК-технологій у просторі освіти. Означено орієнтири успішної реалізації соціально мобільного педагога в сучасній освітній реальності. Описано досвід використання здоров'язбережувальних та ІК-технологій науково-педагогічними працівниками Львівського національного університету імені Івана Франка у процесі формування та становлення соціально мобільних фахівців освіти в умовах пандемії. Практична цінність наукової роботи полягає в обгрунтуванні й узагальненні педагогічних умов оновлення змісту професійної підготовки майбутніх педагогів через призму сформованості в них здатності до соціальної мобільності

Ключові слова: дистанційна освіта, здобувач освіти, здоров’я, здоров’язбережувальне освітнє середовище, ІКТ, освітня технологія, пандемія COVID-19, педагог, соціальна мобільність 